\title{
Scenes and Sensibilities
}

\author{
Will Straw ${ }^{1}$ \\ Universidade McGill
}

\begin{abstract}
RESUMO: Neste artigo, reflete-se sobre os sentidos que o conceito de "cena" adquire em abordagens teóricas que empreendem uma cartografia das sociabilidades emergentes no espaço urbano das cidades. Tentativas de refinar o conceito de "cena", durante a década de 1990, esbarraram em seu caráter escorregadio e anti-essencialista, que parece expandir-se ou contrairse para dar conta de fenômenos relativos às comunidades culturais urbanas do século XX. Adverte-se para o risco de uma celebração exacerbada da efervescência cultural, atribuída às cenas por aquelas abordagens, e discutese a possibilidade de o conceito isolar qualquer agenciamento político relativo a fenômenos culturais urbanos.
\end{abstract}

PALAVRAS-CHAVE: Cenas, Estudos Culturais, Cidade, Sociabilidade, Comunidades Urbanas

ABSTRACT: In this article, the different senses the term "scene" acquires in many theoretical approaches that develop a cartography of the emerging sociabilities at the urban space are brought to discussion. Many efforts on refining the concept have been developed over the past decade, but they had found trouble dealing with its slipperiness and anti-essentializing character, which seems to expand or contract to convey several kinds of phenomena related to twentieth-century urban cultural communities. The article also draws the attention to the risk of exacerbated celebration of the so-called cultural effervescence of the scenes (usually attributed by those accounts) and discuss if the concept could isolate any political agency that may be related to urban cultural phenomena.

KEYWORDS: Scenes, Cultural Studies, City, Sociability, Urban Communities.

${ }^{1}$ Ph.D. em Comunicação pela Universidade McGill, do Canadá. Professor-associado do Departamento de História da Arte e Estudos de Comunicação da mesma universidade. 
Noticed how much Yonge St. at night, particularly south from Gerard, resembles New York's Broadway? The stretch from Gerrard to Shuter is reminiscent of the shootinggallery area bounding Times Square, while the strip south of Shuter improves the way Broadway does in the Fifties ... The cumulative effect of bright lights, noise and hustlers may be tawdry but it couldn't be said that the bars are entirely responsible. Some, like the Bermuda, Steele's and Colonial, which I noticed particularly, have spent a lot in achieving the kind of "shop-fronts" which rank with the best in that kind of modern architecture. Stan Helleur, the Globe and Mail (1958).

In 1950, "The Record Album," Alex Barris' music column for the Toronto Globe and Mail, gradually gave way to another entitled "Night In, Night Out." The new feature still reviewed recordings, but Barris' primary focus was now the circuit of music and entertainment venues which fanned outward from downtown Toronto. This was an age in which the cocktail lounge and performer trio were emerging as dominant features of Toronto nightlife. At this historical moment, venues and performer ensembles were small, even intimate, but they were plentiful as well, and Barris' column could be organized as the passage through an extended scene. As singers and trios settled in for (or concluded) long runs or residencies, the column registered these slow shifts in available entertainment. In the traditions of mainstream midcentury nightlife journalism, covering the club scene meant checking in on new faces and new clubs, catching up with entertainers about whom the buzz was good. Barris' column conveyed the sense of leisurely movement through a cozy, familiar circuit.

Like all scenes, of course, this one was enmeshed within broader economic relations and regulatory regimes. In the early 1950s, the Toronto nightclub industry and the musicians' union battled over the former's increased use of performers from the U.S, as the break-up of swing bands threw more small ensembles onto the market. The Ontario legislature extended the amusement tax from movie houses and concert halls to bars whose entertainment was "not wholly musical". "A comedian adds 15 per cent to the price of drinks," The Globe and Mail reported, "unless he happens to be a wholly musical comedian. Entertainment by magicians, dancers, jugglers and the like also entails the tax" (Globe and Mail, 1950). In 1951, Premier Frost's government tabled new legislation which would extend the tax even further. It 
would apply to bars featuring vocal music, but leave those with instrumental, "background" music untaxed. "A band, according to the premier's interpretation, would be background music, so long as there was no singing, no jokes, no sleight-ofhand, or whatnot" (Globe and Mail, 1951.) An opinion piece entitled "Boiler Boom Bars" bemoaned people's new difficulties in making their conversations heard against the deafening musical backdrop of instrumental trios and quartets (Tumpane, 1950).

Each historical moment like this is ripe with lessons about the role of writing, law and commerce in shaping those phenomena we call "scenes." Urban nightlife nourished the growth of celebrity journalism, which has long traced an unsteady line line between the worlds of transnational celebrity, on the one hand, and localized nocturnal sin and vice, on the other. Along this line, the history of entertainment forms has intersected with each city's distinctive mix of crime and culture, legal and moral regulation. The structure of celebrity culture is condensed in the two-faced character of the night-club, which looks outwards, to the realm of public sociability, and backwards, into the more shadowy worlds of criminality, vice and the night-time economy. Tabloid culture of the 1950 s and 1960 s was fixated on the hypocrisy which is at the heart of this structure; in its more thuggish versions (as with the magazine Confidential) it would endlessly reiterate the connections between public accomplishment and private corruption.

Journalistic coverage of nightlife has often been faithful to one or two deeply entrenched rhetorical forms. One of these is the string of disparate items, famously practiced by Walter Winchell in his newspaper columns and radio broadcasts. Winchell's use of three dots (in his printed columns) or the clicking of a telegrapher's keys (on radio) to separate brief bits of news would be described as distinctly modernist and urban, a work with words which evoked "a man honking in a traffic jam” (Ben Hecht, quoted in Gabler, 1994: 80). In Alex Barris' columns for the Globe and Mail, brief fragments persist, but the telegraphic urgency typical of Winchell is gone, replaced by the hipster's laconic looking-in on a familiar nightlife scene. The other recurrent form in nightlife journalism is the candid photograph, whose power stems, in part, from the clash between the familiarity of the celebrity face and the anonymous, but recognizably tawdry backdrop in which he or she is caught. The first of these forms strives to convey the promiscuous metonymy of urban life, endless 
productive of new bits of sensational information. The second asserts the depth structure of hypocrisy, ritually reasserted in images of the celebrity emerging from a darkened interior into the light of day.

Today, the nightclub is no longer a prominent focus of big-city journalism, in part because the world of celebrities has come to seem more widely dispersed and abstract. Already, by the middle of the 2oth-century, the focus of gossip columnists like Walter Winchell had expanded, from the circumscribed milieu of big city café society to the grander but less concretely grounded spheres of national and international celebrity. A revealing example is that of Midnight, the tabloid newspaper begun in 1954 as a sixteen-page record of Montreal night life. By the 1960s, Midnight had become a hugely successful scandal magazine, still published in Montreal but with a focus and readership that were by now international (Sloan, 2001: 56-57). A similar transformation marks the history of the New York Enquirer which, in 1957, renamed itself the National Enquirer, giving up its emphasis on big cities for an elusive geography of points which seem forever in between. The Montreal Gazette, which published a local nightlife gossip feature until the early 1980s, now offers a column about global celebrities, its items pulled from the internet or media wire services.

Press coverage of Toronto nightlife in the early 1950 s reminds us that urban scenes offer variable economies of urban intensity, distinctive relationships between the scale of the human voice or figure and those forms which surround it. At what point does music cease being the backdrop to conversation or dining and become entertainment? Is the presence of the singing voice enough to bring about this focussing of attention? Similar controversies have accompanied the introduction of television sets into barrooms, where the question of whether they constitute public entertainment or merely decor has long vexed those who license drinking establishments or enforce copyright acts. David Henkin and others have noted the new ratios of the human body to forms of public textuality which took shape, in the 19th century, within the commercial life of cities such as New York (Henkin, 1998: 34.) When advertising messages are twice the size of the people observing them, or when a dozen conversations struggle against an amplified guitar, the status of sociality is altered. These ratios are part of the difficulty in analysing scenes, in 
determining which elements make up their foreground and backdrop. The practices we typically associate with scenes -- public eating, drinking, dancing and talking -involve ongoing negotiation over the appropriate relations between speech and noise, noise and music, attention and distraction, human movement and the physical forms which enclose it.

The quest to ensure a proper proportion between the different levels of urban semiosis will often focus on modern communications forms or technologies and their capacity to interrupt the flow of urban speech and sociability. Public hostility towards boom-box carriers, walkmanwearers or cell-phone users in the early years of each technology centered on the degree to which one could properly intrude upon -- or retreat from -- the seemingly more natural mixes of voice, sound and music which make up the urban soundscape. In all these controversies, questions of public nuisance mix awkwardly with presumptions about urban citizenship and the forms of participation which it presupposes at the most mundane levels. In 1971, after successfully banning newspaper boxes from Montreal streets, Mayor Jean Drapeau told a radio audience he hoped to remove telephone booths and mailboxes, as well, from public spaces in the city (the Gazette, 1971). All of these, he argued, were ugly, but it is worth noting that each supported forms of mediated communication often seen as corruptive of the interpersonal socializing of the urban street.

Put simply, the city provides the crucial mix of people and power, attention and anonymity, money and markets, necessary to generate a genuine cultural scene. It is both content and context, cause and effect, creator and destroyer.

-- Christopher Hume, Toronto Star (2001)

The place of "scene" within cultural analysis seems forever troubled by the variety of tasks it is called upon to perform. How useful is a term which designates both the effervescence of our favourite bar and the sum total of all global phenomena surrounding a subgenre of Heavy Metal music? A quick survey of the music industry magazine Billboard, over a five-year period, found reference to "the L.A. music scene," "the L.A. New Wave scene," "the nation's local music video scene," and "the 
general Middle-Of--the-Road scene” (Billboard 1982: 44; 1981: 55; 1986: 9, 1983: NM1.) Here, as elsewhere, "scene" will describe unities of highly variable scale and levels of abstraction. "Scene" is used to circumscribe highly local clusters of activity and to give unity to practices dispersed throughout the world. It functions to designate face-to-face sociability and as a lazy synonym for globalized virtual communities of taste.

"Scene" persists within cultural analysis for a number of reasons. One of these is the term's efficiency as a default label for cultural unities whose precise boundaries are invisible and elastic. "Scene" is usefully flexible and antiessentializing, requiring of those who use it no more than that they observe a hazy coherence between sets of practices or affinities. For those who study popular music, "scene" has the capacity to disengage phenomena from the more fixed and theoretically troubled unities of class or subculture (even when it holds out the promise of their eventual rearticulation.) At the same time, "scene" seems able to evoke both the cozy intimacy of community and the fluid cosmopolitanism of urban life. To the former, it adds a sense of dynamism; to the latter, a recognition of the inner circles and weighty histories which give each seemingly fluid surface a secret order. In his study of New York City, William R. Taylor refers to those fiction writers (from Washington Irving through Damon Runyon) who claim to find the village within the city (Taylor, 1992: xvi.) The concept of scene steers us towards spaces marked by similar levels of intimacy, without requiring that we view them nostalgically, as remnants of a pre-urban world.

"Scenes," like "vector" suggests both the direction of a movement and its scale. Is a scene (a) the recurring congregation of people at a particular place, (b) the movement of these people between this place and other spaces of congregation, ( c) the streets/strips along which this movement takes place (Allor, 2000), (d) all the places and activities which surround and nourish a particular cultural preference, (e) the broader and more geographically dispersed phenomena of which this movement or these preferences are local examples, or (f) the webs of microeconomic activity which foster sociability and link this to the city's ongoing selfreproduction? All of these phenomena have been designated as scenes. Is a scene the group of people, as they move from place to place? Is it the places through which they move? Is it the 
movement itself? (A recent book on musical styles in Brazil has the title "Funk and Hip-Hop Invade the Scene," as if a scene were a pre-existing cultural space waiting to be occupied and defined (Herschmann, 2000)).

To pose the question more concretely: are Laika, la Cabane and Casa de Popolo (bars/cafés on Montreal's St. Laurent Boulevard) the hosting places for preexisting scenes, spaces productive of their own scenes, moments in the itinerary of a scene (in the course of a night, or over many years), local examples of scenic phenomena whose true scale is international, or points within networks of social, cultural and economic interconnection which are themselves the real scenes? Is Laika most effectively described as one outpost of the local Montreal French house scene, the birthplace of its own Laika scene, a pre-clubbing pit stop on Saturday night, or part of the new international scene of cafes in which djs spin records for seated customers? Or is it an economic node, the place where Francophone and Anglophone cultural studies academics, aspiring djs, graphic designers, multimedia artists and writers may all meet to conduct transactions at the highest levels of mutual comfort?

The risk in speaking of "scenes" is that the word will become little more than the latest concept deployed to convey the messy indeterminacy of urban life. It gestures towards the Simmelian sense of the city as a place of stimuli and sensation, then adds to this a more recent concern with subcultures and contemporary tribalisms. A decade of writing in popular music studies has sought to refine the notion of "scene", but the slipperiness remains. In my own contribution to this effort, I sought to define scenes as geographically specific spaces for the articulation of multiple musical practices (Straw, 1991). Like most attempts at definition, this could not diminish the pertinence and popularity of other uses -- like "international hardcore scene" (Billboard, 1994) -- whose sense of space was very different.

The semantic space occupied by "scene" expands and contracts between two extremes in urban cultural analysis. At one of these extremes, we begin with the visibly social cityscape; the concept of "scene" invites us to delineate its underlying order. The designation of scene gives depth to the theatre of urban sociability, to the worlds of restaurants, cafes and other spaces of congregation. Calling these phenomena "scenes" means seeing them in terms of their obscured logics and their participation in the ongoing realignment of social energies. The description of people 
gathered in a bar as a "scene" presumes that moments of seemingly purposeless sociability are caught up in the production of conspiratorial intrigues, projects and group identities. "Scene" thus allows an order to intrude upon our sense of the city as merely aesthetic -- that is, as a space of sensation and theatricalised encounter. Through it, we begin to glimpse a cartography of the city's social regions and their interconnection. In this sense, "scene" is one resource in the elaboration of a grammar of cultural ordering. (At the same time, as Alan Blum's article in this issue suggests, it requires its own grammar.)

At another extreme, though, "scene" serves to loosen up a sociological analysis rather than to give it form. "Scene" is, arguably, the most flexible term in a social morphology that includes such categories as art world, simplex or subculture. One of its genealogies (the dullest, admittedly) takes us into the sociology of work and organizations. In a influential 1959 article, "Bureaucratic and Craft Administration of Product," Arthur Stinchcombe asked whether all workplaces, under conditions of advanced capitalism, would necessarily show tendencies towards rationalization and bureaucratization (Stinchcombe, 1959). Many did, but in the construction of postwar tract homes, Stinchcombe found that work contained features which might well have been considered outmoded, remnants of an earlier, "craft" mode of production.

On construction sites, bonds of kinship and friendship seemed to shape the sharing of tasks and the precise protocols for their accomplishment. Skills and knowledges passed between members of the workplace in ways that more closely resembled the circulation of folklore than the institutionalized transmission of instructions.

At one level, Stinchcombe may simply have observed (but left unnamed) the homosociality of construction labour. Nevertheless, his work opened one pathway into subsequent analysis of the cultural industries, into a tradition that emphasized these industries' permeable boundaries and the overlapping, within them, of work and sociality (see, for example, Hirsch, 1972). In historical writing, ideas such as these have been extended backwards, as in William Taylor's portrait of early 2oth century urban commercial culture as the locus of face-toface exchange and localized mythologies (1992). Such ideas may be seen to anticipate, as well, accounts of post- 
Fordist economic activity which see such activity as embedded within informal connections and an ongoing attentiveness to rumour and opportunity. Throughout these works, models of economic or industrial organization dissolve within a broader notion of social and cultural worlds, of phenomena that resemble scenes. Re-reading Stinchcombe's work, we might well ask from what analytic distance the construction of homes might be most usefully viewed -- as an economic activity whose organizational logic is to be deciphered, or as one of the activities of a particular scene (along with such behaviours as drinking and recruitng.) At what point should the language typical of organizational sociology give way to another developed in the analysis of creative worlds -- languages which has given us categories like Howard Becker's "art world" (Becker, 1982) or the loosely organized "simplex" of Nashville session musicians described by Peterson and White (1979).

"Artworld," or "simplex"-- like "subculture" or "movement" -- circumscribe activities and identities more tightly than does the notion of "scene." In so doing, do such terms resolve the elusive slipperiness of scenes, or merely reify some of their transitory features? With the increased attention to the urban within cultural studies, categories like subculture, community or movement have come to seem less and less able to contain the variety of activities which transpire within them, or the fluid mobility in which they participate. "Scene" seems more efficient at expanding to encircle these activities, as in Barry Shank's definition of scene, which casts it as "an overproductive signifying community". Within a scene, Shank elaborates, "far more semiotic information is produced than can be rationally parsed". (Shank, 1994: 122). We should take from this more than the claim that all activities of practical or economic purpose produce an affective surplus or elicit unintended consequences. Part of the "overproductive signifying" character of scenes, arguably, is their broader role in realigning the cartographies of city life, even when the activities of scenes seem intended to express or occupy very precise places within such cartographies.

Distrust of the notion of "scene" often stems from the fact that it seems to isolate no viable political agency. Indeed, theorizations of "scene" rarely name anything to which scenes might be opposed. (The concept may be opposed to those of "community" or "subculture", but the phenomenon itself has no enemies.) If the term's function is simply an anti-essentializing one, limited to its capacity to loosen 
up more rigid notions of social ordering, "scene" will find its political edge only within arguments which proffer the indeterminacy of urban scenic life as a challenge to entrenched unities. In this, an embrace of "scene" may be one more event in the ongoing (if never total) subsumption of cultural studies work within aestheticizing accounts of urban space. A decade ago, the move to investigate space seemed to unfold under the influence of Foucault or Lefebvre, whose claims about space as produced seemed to authorize the analysis of circumscribed sites with clear significance in the dilineation of power. The ascendant influence of Simmel and Benjamin has reoriented this spatial turn, however. An unending flood of work now seeks to capture a reordering of perception presumed to have been produced within the conditions of urban modernity.

The concept of "scene" may flourish within this turn, as one more metaphor for urban flux and excess. No original sense of the term is being betrayed here; the slipperiness which authorizes his sense of "scene" has long been its companion. Nevertheless, the concept's intermittent appeal to popular music scholars has stemmed from the sense that it will help to resolve a number of thorny questions, most notably that of relations between the global and the local. As long as people continue to speak of global trance scenes or the "monster L.A. lounge scene," "scene" will suggest more than the busy fluidity of urban sociability. It compels us to examine the role of affinities and interconnections which, as they unfold through time, mark and regularize the spatial itineraries of people, things and ideas.

$* * * * *$

In the United States, the cradle of mass culture, the intellectual no longer scorns fashion. He is free to embrace it. Since the Kennedys, wide-eyed beauties try to sound serious occasionally and Establishment scholars to act silly. Among other things, the party that Truman Capote gave in November 1966 for the 540 he deemed elite indicated that a former Harvard professor like Arthur Schlesinger, Jr., and a dress designer like Oscar de la Renta are now in the same peer group. The professor writes movie reviews for Vogue. As for Mr. Capote, he has raised the intellectual sights of at least two members of the Best-Dressed List, Mrs. William S. Paley and Princess Stanislas Radziwell. He introduced Mrs. Paley, the wife of the chairman of the Columbia Broadcasting System, to the writings of Marcel Proust. (Bender, 1967: 19) 
The scene described above -- an almost perfect example of what Sally Banes, likewise writing about the 1960 s, called "the multiple possibilities of a concrete postmodern worldview" (1993) --- supports a widespread sense that scenes are fluid, disruptive phenomena. This fluidity has seemed to mark the scenes of urban culture since the early 20th century, when the gossip columnist Maury Paul would note that "society isn't staying home any more. Society is going out to dinner, out to night life, and letting down the barriers" (quoted in Allen, 1993: 73.) In his history of New York nightlife in the 1920s, Lewis Erenberg captures the multiple senses of "scene" in his description of the new cabaret-restaurants which served as spaces for public dancing.

The dance floor, the absence of large proscenium arch stages, and the closeness of the audience seated at tables made the room a scene of expressive activity. The entire restaurant became the setting for performance, and customers themselves could not escape becoming involved in the action and spontaneity of the moment. In a theatre, expressiveness was limited primarily to hired performers. In the cabaret, audiences and performers were on the same level, and thus expressiveness spread to the audience as well (1991: 124).

Just as they remove the barriers dividing performers from audiences, the new cabarets are seen to bring the upper-class into contact with others, solidifying that sense of nightlife as social tourism which lingers today. Twentieth-century scenes in general, from the café society of the 1920s through the East Village in the 1980s, have been cast as experiments in social change and radical juxtaposition. By the 1960 s, leisurely movement through a city's network of bars and lounges, of the sort which shaped the pace and style of so many nightlife columns of the 1950s, had given way to descriptions which sought to trump each other in their accounts of busy, unexpected social promiscuity. (Andy Warhol on the 1960s: "It was fun to see the Museum of Modern Art people next to the teeny-boppers next to the amphetamine queens next to the fashion editors.") La Presse's 1968 description of Montreal's debutante ball at Place des Arts reveled in its mixing of fashion models, rock bands, high society and Pierre Trudeau (La Presse, 1968).

Against a seductive sense of scenes as disruptive, I would nevertheless insist on their capacity to slow the turnover of urban novelty. Scenes are, much of the time, lived as effervescence, but they also create the grooves to which practices and affinities become fixed. 
Chance encounters on a street or in bars often require, to be smooth and successful, the resuscitation of connections or mutual interests now marginal to the rest of our lives. In such encounters, and in their repetition, knowledges are reinvigorated and the peripheries of our social networks renewed. Such occasions are like the sedimentation of artefacts or architectural forms within cities; through them, the city becomes a repository of memory.

Scenes extend the spatialization of city cultures through the grafting of tastes or affinities to physical locations. Within scenes, tastes or affinities become organized as itineraries across series of spaces. In this respect, scenes absorb (and sometimes neutralize) the energies of vanguardish activities. Scenes regularize these activities within the rituals of drinking or dining, or subject them to the frequency of accidental encounters. The fragmentation of local musical or literary activity across a range of sites -- at one level, the sign of a scene's health and growth -will extend the itineraries necessary for full participation in these scenes. In this process, the spectacular loses visibility, dispersed within multiple sites of encounter or consumption. Avantgardes, whose purest forms define themselves in terms of time and movement, run aground when their occupation of space makes them one more set of points on a cultural map, or when their expansion diverts their members' energies towards the work of making the rounds.

The development of scenes over time is, at one level, a product of differences in the rates at which tastes and practices change relative to places of congregation or sites of commerce. Subcultures with special interests (1960s Québécois yé-yé music, for example) deposit artifacts and produce spaces throughout the city in ways which give these scenes traction, slowing their dissolution or obsolescence. Sheenagh Pietrobruno's analysis of salsa dancing in Montreal expertly traces the role of new businesses (bars and dancing schools) in perpetuating the sense of a lively, self-renewing scene (Pietrobruno, 2001). In Montreal, as well, the final, complete dispersal of a late 1980 s academic/art/music/journalism scene in Montreal has been slowed by the persistence of places like the bar/restaurant La Cabane, where that scene's remnants (like myself) intermittently coalesce and recover a sense of scenic coherence. Were it to close, its constituent parts would be unlikely to reassemble elsewhere. Already, some of those parts have been pulled 
elsewhere, in multiple directions: towards the Plateau Press Club meetings at Nantha's Kitchen, the boozy middle-aged Anglophone set at Elsye's, or the novel mixes of generation, language and profession produced within newer bars such as Bily Kun.

I have argued elsewhere that scenes function more and more as spaces organized against change (Straw, 2001). Within them, minor tastes and habits are perpetuated, supported by networks of small-scale institutions, like record stores or specialized bars. At this level, scenes might be seen as conservative, asserting the values of diversity dispersed across space over those of regularized obsolescence and renewal in time. (In this respect, as well, scenes may offer a radical antidote to an economy of ongoing obsolescence and short-term fads.) A more useful diagnosis might note the increased frequency with which affinity cultures (such as those surrounding Doom Metal or drum-and-bass music) find coherence through the slow elaboration of ethical protocols to be followed by those moving within them. These protocols have displaced that polemical, even combative engagement with others which marked the spectacular subcultures of the 1960s and 1970s. Music scenes ground their distinctiveness in an ethics of cultural consumption (which music to buy, and where?). Around these foundational ethics gather norms to regulate everything from greeting rituals to the sharing of resources. These norms themselves lose visibility within the mundane activities of buying drinks or discussing shared interests, but they are perpetuated within such activities, absorbed within the thicker tissues of urban sociability.

In discussing the status of cities vis-à-vis the nation or other, transnational unities, we might remember that urban scenes will almost always be perceived as lively, productive social spaces. A sense of their effervescence will persist even when the strength and independence of the national cultures to which they belong are threatened or allowed to wither. National projects to support global cultural diversity, for example, lose their mobilizing force when the everyday experience of urban scenic life seems already to offer such diversity, when culture is no longer perceived as a scarce resource. The virtue of scenes is that they offer laboratories for cultural citizenship which are largely untainted by the sense of unfulfilled collective obligation which national cultural policy so often seeks to impart (Miller, 1993: xi). The danger 
is that the richness of scenes may offer an alibi, throwing into doubt the pertinence of a broader political or economic analysis of the cultural sphere. If, indeed, culture life seems richest at the ground level of urban sociability, we need a cultural activism which both challenges the complacency of scenes and more widely disseminates their virtues.

\section{Acknowledgements:}

Thanks to Aleksandra Tomic for her expert research assistance, and to Sheenagh Pietrobruno for our conversations about scenes. Thanks, as well, to Alan Blum and Geoff Stahl, whose own pieces for this issue (the only ones I had read before writing this one) were great inspirations.

\section{References:}

Allen, Irving Lewis (1993). The City in Slang: New York Life and Popular Speech. New York and Oxford: Oxford University Press.

Allor, Martin (2000). "Placing Sites: Modeling Mediations of Local Cultural Activity.” Paper presented at the annual conference of the Canadian Communications Association, Edmonton, Alberta, May 28, 2000.

Banes, Sally (1993). Greenwich Village 1963: Avant-Garde Performance and the Effervescent Body. Durham and London: Duke University Press.

Becker, Howard (1982). Art Worlds. Berkeley, CA: University of California Press.

Bender, Marjorie (1967). The Beautiful People. New York: Coward-McCann, Inc.

Billboard (1981). "Nobody Wants To Rock Anymore: Producer Chapman Airs Views At Copyright Meeting"." Billboard, January 31, 1981, p. 55.

Billboard (1982). "Chartbeat." Billboard, February 13, 1982, p. 64.

Billboard (1983). "All's Fair On Live Ride." Billboard, p. 9, 1983, p. NM1.

Billboard (1986). "U.K. To Meet the 'New Age': Beggars Banquet Sets National Push." Billboard, January 25, 1986, p. 9. 
Billboard (1994). "Acid-Jazz Penetrates U.S. Market: Genre Catches On With Success of US3, Heavies," April 30, 1994, p. 1.

Erenberg, Lewis A. (1981). Steppin' Out: New York Nightlife and the Transformation of American Culture, 1890-1930. Chicago: University of Chicago Press.

Gabler, Neal (1994). Winchell: Gossip, Power and the Culture of Celebrity. New York: Alfred A. Knopf.

Gazette, the (1971). 'City studies ban on phone booths, mailboxes, too,' The Gazette, November 22, 1971, pg. 3

Globe and Mail (1950). "Inspectors Scan Free Bar Shows for Taxable Entertainment," April 27, 1950.

Globe and Mail (1951). “Tavern Entertainment: Music Only Ruled Okay, Song Means Tax to Pay," March 31, 1951.

Helleur, Stan (1958). "It's Entertainment," the Globe and Mail, September 11, 1958, p. 31.

Henkin, David M. (1998). City Reading: Written Words and Public Spaces in Antebellum New York. New York: Columbia University Press.

Herschmann, Michael (2000). O Funk e o Hip-Hop invadem a cena. Rio de Janeiro: Editora UFRJ, 2000.

Hirsch, Paul (1972). "Processing Fads and Fashions: An Organization Set Analysis of Cultural Industry Systems," American Journal of Sociology, 77, pp. 639659.

Hume, Christopher (2001). "Art of the city Exhibit shows how relationship with cultural creativity, or lack thereof, can make or break a metropolis." Toronto Star, online edition, March 10.

Miller, Toby (1993). The Well -- Tempered Self: Citizenship, Culture, and the Postmodern Subject. Baltimore and London: The Johns Hopkins University Press.

Peterson, Richard A., and Howard G. White (1979) "The Simplex Located In Art Worlds." Urban Life, 7, no. 4 (January), 411-439.

Pietrobruno, Sheenagh (2001). Salsa and its transnational moves: the commodification of Latin dance in Montreal. Montreal: Department of Art History and Communications Studies, McGill University. Unpublished doctoral dissertation.

Presse, la (1968). "Quand la Place des Arts prend des airs de discothèque," October 21, 1968, p. 13.

Shank, Barry (1994). Dissonant Identities: The Rock'n'Roll Scene in Austin, Texas. Hanover and London: Wesleyan University Press.

Sloan, Bill (2001). "I Watched A Wild Hot Eat My Baby!" A Colorful History of Tabloids and Their Cultural Impact. Amherst, N.Y.: Prometheus Books. 
Stinchcombe, Arthur I. (1959). "Bureaucratic and craft administration of product." Administrative Science Quarterly, 4 (1959), 168-187.

Straw, Will (1991). Systems of Articulation, Logics of Change: Scenes and Communities in Popular Music,' Cultural Studies, Vol. 5, No. 3 (October) 361-375.

Straw, Will (2001). “Consumption.” In Simon Frith, Will Straw and John Street, eds., The Cambridge Companion to Rock and Pop. London: Cambridge University Press.

Taylor, William R. (1992). In Pursuit of Gotham: Culture and Commerce in New York. New York and Oxford: Oxford University Press.

Tumpane, Frank (1950). "Boiler Boom Bars," The Globe and Mail, August 30, 1950.

Anne Richer, "Quand la Place des Arts prend des airs de discothèque," La Presse, October 21, 1968, p. 13. 